\title{
小児用嚥下補助ゼリーのレオロジーによる評価研究
}

\author{
下川健一，板橋知子，山㟝紀子 , 北原嘉泰 , 石井文由* \\ 明治薬科大学薬学部医療薬学教育センター
}

\section{Rheological Study on Jellies Used to Aid Deglutition in Pediatric Patients}

\author{
Ken-ichi Shimokawa, Tomoko Itabashi, Noriko Yamazaki, \\ Yoshiyasu Kitahara and Fumiyoshi Ishii * \\ Department of Health Care and Sciences, \\ Faculty of Pharmaceutical Sciences, Meiji Pharmaceutical University \\ $\left[\begin{array}{l}\text { Received A pril 2, } 2009 \\ \text { A ccepted July 30, } 2009\end{array}\right]$
}

\begin{abstract}
Rheological measurements were made on commercial jelly products for facilitating medication in children in order to examine their physical properties and effect on children's compliance. The measurements were made on mixtures of the drug (Clarith dry syrup for pediatric use) and various jelly products.

There were large differences in rheograms as well as particularly remarkable differences regarding yield values, presence of thixotropy and thixotropy area. Children favoured jellies showing thixotropy, and the extent to which such jellies were liked increased as thixotropy increased. Moreover, we were able to predict children's preference using the rheograms. These results indicate parameters that would be useful in the development of jellies that facilitate medication effectively.
\end{abstract}

Key words — compliance, deglutition, jelly, pediatric patients, rheology

\section{緒言}

小児における薬剂のコンプライアンスに関して多くの 報告があり1-5)，コンプライアンス低下の原因としては 薬斧の味，においや舌触り等がある，兴の中でも特に， 薬斉特有の「苦み」や「ざらつき」などが大きくかかわっ

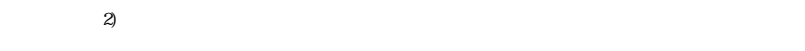
顆粒剂で, 产の次が水剂やシロップ剂であると報告され ている3 . 製薬企業は小児用製剂として，シロップ剂や ドライシロップ斉などの製品を作ることで対応してい る .しかしながら，小児の薬剤のコンプライアンスに関 してアンケート調査をしてみると，本来苦い薬阁に甘味 料等で味付けをしても，薬剂自体の苦みは消えず，ある いは甘すぎたりして劇的なコンプライアンスの改善はみ られないのか現状である．乥こで，一般的にコンプライ アンスを改善するために, 薬剤を砂糖，はちみつ,シロッ プ , チョコレート，ジュースやアイスクリーム等の子供 が好きな食品といっしょに服用するなどの工夫がなされ ている3 . 最近では, トロミ調整食品や嚥下補助ゼリー なども市販されるようになり，弚れらは徐々に広まりつ つある ${ }^{6-11)}$.これらの製品は, 当初, 高齢者や入院患者
を対象にして開発されたものであるが，子供が好むいち ご,ピーチあるいはチョコレート等の味付けに変えるこ とで，小児が服用できるように改良されたものであ $ろ^{12)}$. これらの嚥下補助ゼリーに関しては, 高齢者を対 象とした嚥下補助ゼリ一の評価に関する報告9-12) はある が，小児を対象にした嚥下補助ゼリ一の報告は少ない .

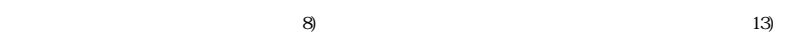
関して報告されているが, 各種小児用嚥下補助ゼリーの レオロジー特性に関する流動性から評価した報告はな い.

そこで本研究では，小児を対象とした嚥下補助ゼリー に注目し，各種市販の小児用嚥下補助ゼリーに関するレ オロジー測定を行い，弚の物性と小児の服用に関しての 考察を行った .

\section{材料}

ヨーグルトは「CO-OP プレーンョーグルトビフィズ ス ${ }^{\circledR}$ で日本生活協同組合連合会のものを使用した . 各 種嚥下補助ゼリーに関して,「ソフティア ${ }^{\circledR} 2$ ゲル(ゼリー 食用)」はニュートリー株式会社製，「やさしく・おいし く水分補給 ${ }^{\circledR}$ ははバランス株式会社製，「お薬飲めたね ${ }^{\circledR}$ 


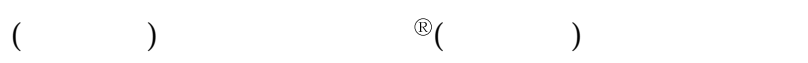
ね ${ }^{\circledR}$ (チョコレート味)」は株式会社龍角散製のものを使用 した .アクエリアス ${ }^{\circledR}$ は日本コカ・コーラ株式会社製， ココアは「バンホーテン衿じわいココア」で明治乳業 株式会社製，オレンジジュースは「サンキスト ${ }^{\circledR} 100 \%$ オレンジ」およびアップルジュースは「サンキスト ${ }^{\circledR} 100$ \%アップル」で森永乳業株式会社製のものを用いた . ま た，「クラリスドライシロップ ${ }^{\circledR} 10 \%$ 小児用」は大正製 薬株式会社製のものを使用した .

\section{方法}

\section{1. 各種試料の $\mathrm{pH}$ 測定}

各種嚥下補助ゼリーの pH はHORIBA pH/Ionメー ター(F-53型，(株)堀場製作所)を用いて产れ光れ測定し た.なお，お薬飲めたね(いちご味)，やさしく・おいしく 水分補給，ヨーグルトに関しては各試料を無のまま測定 した 一方, 弚の他のアクエリアス,アップルジュース， オレンジジュースおよびココアに関してはソフティアを 光れ光れ添加して補助ゼリーの状態で pH を測定した .

\section{2. レオロジー測定}

嚥下補助剂としての試料は飲みやすさの基準として， 一般的に飲みやすいと評価の高いヨーグルト ${ }^{14-16)}$, 嚥下 補助ゼリーとして販売されている「お薬飲めたね(ピー チ味)」,「お薬飲めたね(いちご味)」,「お薬飲めたね (チョコレート味)」, 同樣に嚥下補助ゼリーとして販売 されている「やさしく・おいしく水分補給」, 嚥下困難 な高齢者のために開発された嚥下食用テクスチャー(食 感改善剂の「ソフティア」を用いてレオロジーを測定 し，比較・検討を行った .ソフティアは嚥下食用テクス チャー改良剂であり, 精製水, オレンジジュース, アッ プルジュース, アクエリアスあるいはココアで $0.75 \%$ に調製した。なお，溶解後， 60 分間 $4{ }^{\circ} \mathrm{C}$ で完全にゲル 化させた後, 実験に使用した。また，薬刘は医薬品との 相互作用や苦味の面で一般的に服用が難しいとされる クラリスドライシロップ小児用を使用した .

レオロジーの測定には, 単一円筒形回転粘度計のせん 断速度・せん断応力制御型レオメーター(RC 20型, レ オテック , ドイツ)を使用した ${ }^{17,18)}$. 測定温度は , サーモ スタット・ジャケットにより口腔内温度を想定した 37 土0.1ㄷ で行った .レオメーターに使用される内円筒(ボ ブ)およびカップのサイズは, 円筒の外径が $25.0 \mathrm{~mm}$, カップの内径が $26.5 \mathrm{~mm}$ で, 弚の間のギャップは 1.5 $\mathrm{mm}$ であった . せん断速度は, 内円筒が $1,000(1 / \mathrm{s})$ に達 するまで毎秒 5.5(1/s)で上昇させ，1,000(1/s)に到達した 時点で 20 秒間保持した. 弚の後, 1,000(1/s)から $O(1 / \mathrm{s})$ まで毎秒 5.5(1/s)でせん断速度を減少させて測定を行っ た.試料は 1 回の測定につき $15 \mathrm{~g}$ を用いて，1つの試料 につき，।「試料のみ(攪拌なし)」，II試料のみ(攪拌
あり)」および川I!試料にクラリスドライシロップ(1g) を添加したもの(攪拌あり)」の3つの条件において产れ 光れ測定を行った .ここで，川の「攪拌あり」とはクラ リスドライシロップを添加時に混ぜるために攪拌したと いう意味で，川の「攪拌あり」とは川川のコントロールと して, 薬阁をを添加せずに基質(ヨーグルトや嚥下補助ゼ リーなど)をかき混ぜることで，基阁の状態がドライシ ロップの添加の有無だけの違いとした .乥して，।の「攪 拌なし」とは基剂のみを用い，攪拌操作をしていない試 料である .

\section{結果および考察}

\section{1. 各種試料の $\mathrm{pH}$ 測定}

本実験で用いた各種試験用試料は口腔内での味(特に 酸味など)や食感が $\mathrm{pH}$ により大きく変化するとともに 服用に関するコンプライアンスにも大きな影響を与える 因子の一つと考えられる．弚こで各種試料の $\mathrm{pH}$ を測定 した結果を表 1 に示す. 表 1 において , pH の低い順番 に(1)ソフティア+アクエリアス , (2)お薬飲めたね(いち ご味) , (3)フティア+アップルジュース , (4)フティ ア+オレンジジュース, (5)やさしく・おいしく水分補 給 , (6)ヨーグルト，(7)ソフィア+ココアであった . (1) から6に関しては pH 3.50〜4.28 と弱酸性を示し，77は pH 6.75 でほぼ中性であった . ソフティアの主成分はデ キストリンと増粘多糖類で，食品等に添加して高齢者の 嚥下を補助するために開発されたものである . ソフティ ア自体は粉末であるので , 混合した飲料等の $\mathrm{pH}$ が反映 されていると思われる . また , ソフティア以外の製品は 弚れ自体の $\mathrm{pH}$ である.薬剂と一緒に飲みやすいといわ れるヨーグルトの $\mathrm{pH}$ が 4.28であったことから，pH に 関しては弱酸性のものが飲み込みやすい一つの要因であ ると思われた .

\section{2. レオロジー測定}

試料を咀嚼する場合, 試料が口腔内でせん断応力を加 えられることにより, 流動性の低いゲル状態から流動性 の高いゾル状態に変化することで, 飲み込みやすくなる ことが考えられる．光こで，レオメーターを使用し，チ キソトロピー特性を計時的に測定することで，食感に対

表 1 . 各種小児用嚥下補助ゼリーの pH 值

\begin{tabular}{ll}
\hline 各種小児用㫶下補助ゼリー & $\mathrm{pH}$ \\
\hline (1) ソフティア+アクエリアス & 3.50 \\
(2) お薬飲めたね (いちご味) & 3.57 \\
(3) ソフティア+アップルジュース & 3.61 \\
(4) ソフティア+オレンジジュース & 3.67 \\
(5) やさしく・おいしく水分補給 & 3.81 \\
(6) ヨーグルト & 4.28 \\
(7) ソフティア+ココア & 6.75 \\
\hline
\end{tabular}


する数値化を試みた .

まず，最初に判定の基準となるヨーグルトの測定結果 を図 $1 \mathrm{~A}$ に示す．なお，図中の流動曲線について，। . 「試料のみ(攪拌なし)」は○印，II「試料のみ(攪拌あり)」 は $\triangle \sum^{2}$ ， III「試料にクラリスドライシロップを添加した もの(攪拌あり)」は口印で关れ光れ表示した。はは降伏 值が 34.9Pa と高く, 構造粘性を有する特徵的なヒステ リシスループを描いており，外力(せん断応力)を加える ことにより一気に液体に近い状態になることがわかっ た。川および川では攪拌したことで構造粘性が破壞さ れ，粘性が低くなっている．しかしながら，॥および川 の曲線に大きな違いはないため，攪拌により流動性の高 いゾル状態に近づいたことがわかる．これは，攪拌によ りヨーグルトの高分子成分の安定化構造状態が変化し, 粘性が低下したものと考えられる．

次に , ソフティアを用いて , アップルジュースで調製 した嚥下補助ゼリーについての測定結果を図 1 B に示 す．।については，ヨーグルトに比べ降伏值(10.3Pa)お よびヒステリシスループ内の面積が小さくなっている . Iおよび川には大きな違いはないが , IIIにおいてはクラ リスドライシロップを添加することにより， I に比べヒ ステリシスループ内の面積が若干大きくなっていること から, 薬斉の添加によりソフティアの構造粘性か増加し たと思われた

ソフティアを用いて , オレンジジュースで調製した嚥 下補助ゼリーについての測定結果を図 $1 \mathrm{C}$ に示す . 3曲

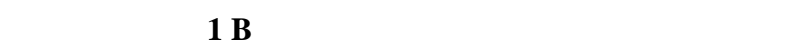
よび川の降伏值はとれ炎れ 10.0Pa と 9.8Paで曲線につ いて大差は認められず, IIIの降伏值が 14.2Pa と増加し， 薬剂とソフティアによって構造粘性が生じていることが わかる .また , この構造粘性によりヒステリシスループ 面積の広がり，つまりチキソトロピーの増大を生じてい ることも明らかとなった .さらに, Iおよび川と比較し て, 降伏值の違いと流動曲線のピーク(せん断速度が必 要な最大速度に達してから減少に転じる点)からの下降 時にも，高速せん断によって破懐された構造粘性の復元 速度に違いがあることも明白となった．

ソフティアを用いて , アクエリアスで調製した測定結 果を図 1 D に示す . これも 3 曲線の傾向は図 1 B のアッ プルジュースに似ており，।および川についてほとんど チキソトロピー性はなく，川Iおいて若干のヒステリシ スループ面積の広がりを生じている . アクェリアスは他 のジュースと比較して , ヒステリシスループの面積が小 さく,さらに降伏值(7.8Pa)も低いため, 小さな外力で も一気に粘性が低下することが示された .

ソフティアを用いて，精製水で調製した測定結果を図 $1 \mathbf{E}$ に示す． I は降伏值が 47.6Pa と高く，ヒステリシ スループを描いており, かつ流動曲線のピーク時に構造 粘性が完全に破壊されたため，弚の下降時には急激に粘 性も低くなることがわかった . 炎して，Iについても I
ほどではないが降伏值は 25.1Pa と高かった．また，下 降時にはドラスティックに粘性が低くなっていた．しか しながら， Iおよび川と比較して川I゙は降伏值が 9.2 Pa と小さくなることから，精製水により調製したソフティ ア基剤に薬剂が作用して , ソフティア基剂の構造粘性を 弱める方向に働いたと思われる．

ソフティアを用いて，ココアで調製した測定結果を図 $1 \mathbf{F}$ に示す . 3曲線のヒステリシスループの傾向はほぼ 同一であった . ソフティアにココアを添加したものは , ココア中の線維や高分子成分の影響も考えられたが，ヒ ステリシスループの傾向は図 $1 \mathrm{~B}$ および $1 \mathrm{D}$ とよく類似 していることがわかった．したがって，図 1 B 1 F の レオロジー測定においては , ドライシロップを添加して も流動曲線への影響が少ないことが示唆された。

次に，やさしく・おいしく水分補給を用いた測定結果 を図 1 Gに示す．3曲線が光れ光れ違うヒステリシス ループを描いており，।の「試料のみ(攪拌なし)」に比 ベ, ॥の「試料のみ(攪拌あり)」はせん断応力がほぼ半 減した．これは攪拌操作により，やさしく・おいしく水 分補給の基剂中の水和構造が崩れたことを示している. これに対し，川川の「試料にクラリスドライシロップを添 加したもの(攪拌あり)」では，せん断応力が। の約 1.5 倍 に増加した .これはドライシロップを添加することで構 造粘性か増加し，ヒステリシスループを大きく増大させ ており，基剂と薬剂ドライシロップの相互作用が増大 し, 光の結果光のレオロジー特性も大きく変化した .

お薬飲めたね(ピーチ味)を用いた測定結果を図 $1 \mathbf{H}$ に 示す．3曲線がほぼ同樣な流動曲線を描いており，। お よび川に対して川がドライシロップを添加した分だけ， 同じせん断速度を有するには，わずかではあるがより多 くのせん断応力が必要であった．しかしながら，図 $1 \mathbf{G}$ のやさしく・おいしく水分補給と比較して, チキソトロ ピー特性はほとんど観察されなかったことから，お薬飲 めたね(ピーチ味)はドライシロップの添加によっても構 造粘性を有することなく，薬剂と基剂間で物理的相互作 用はほとんど生じないということが明らかになった .

お薬飲めたね(いちご味)を用いた測定結果を図 1 I に 示す．これは図 $1 \mathbf{H}$ のピーチ味と異なり，3つの曲線が 光れ光れ違う流動曲線を描いた．光して，せん断応力に 対して流動曲線の形状が明らかに異なっていた .これは 図 $1 \mathrm{G}$ のやさしく・おいしく水分補給と同樣にドライ シロップの添加で構造粘性か増加し，谷のレオロジー特 性が大きく変化した .

最後に,お薬飲めたね(チョコレート味)を用いた測定 結果を図 $1 \mathbf{J}$ に示す . これは図 $1 \mathbf{H}$ のピーチ味および図 1 I のいちご味と異なる流動曲線を描いた，弚して，せ ん断応力に対して।，川および川川の流動曲線の形状が明 らかに異なっていた .この違いに関しては, チョコレー 卜の味付けのために添加した成分(例えば，ココアパウ ダーなど)による構造粘性の増大を引き起こしたためと 


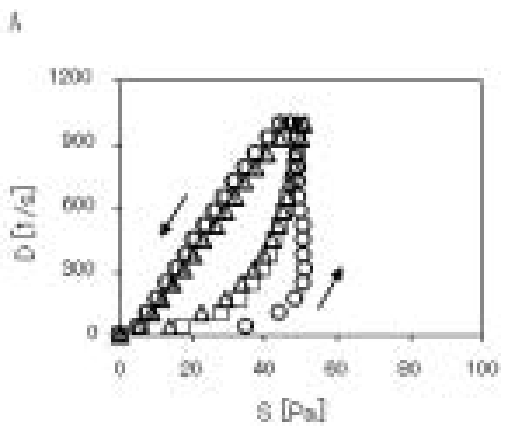

c

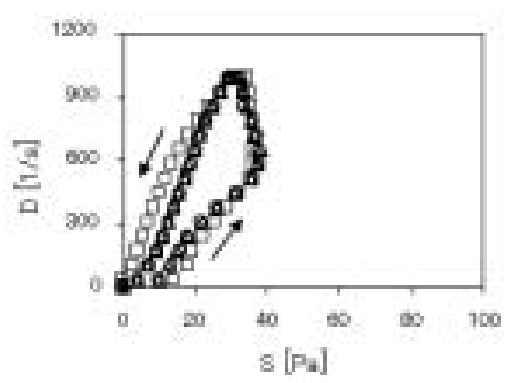

E

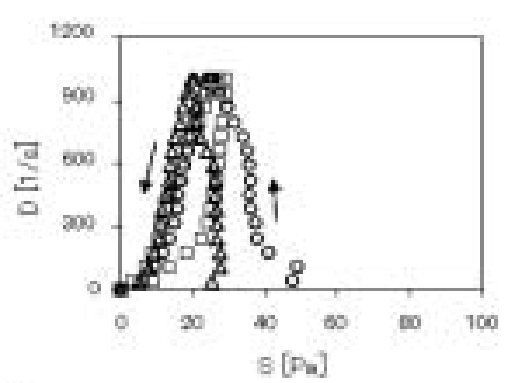

G

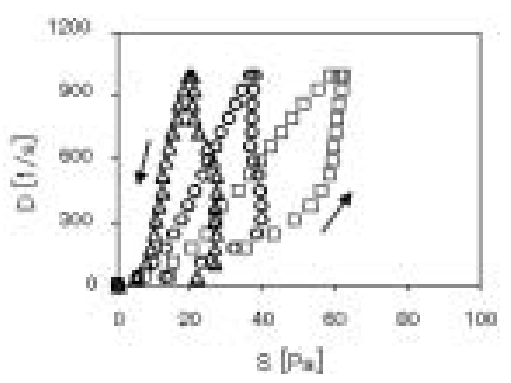

I

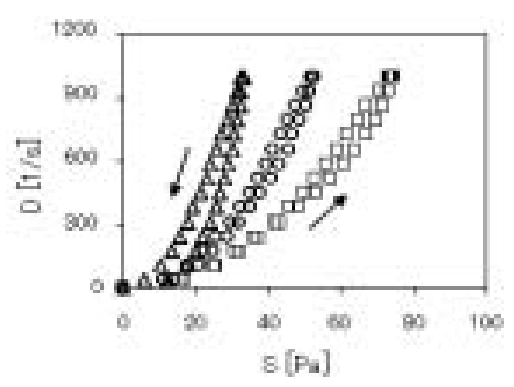

B

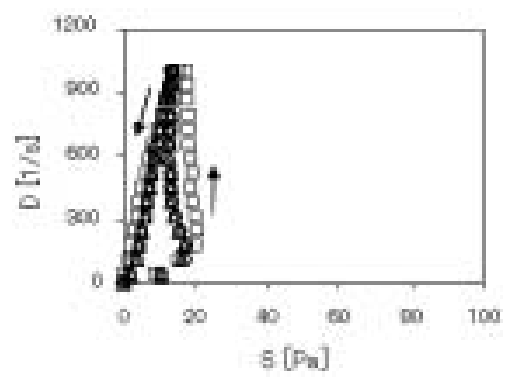

D

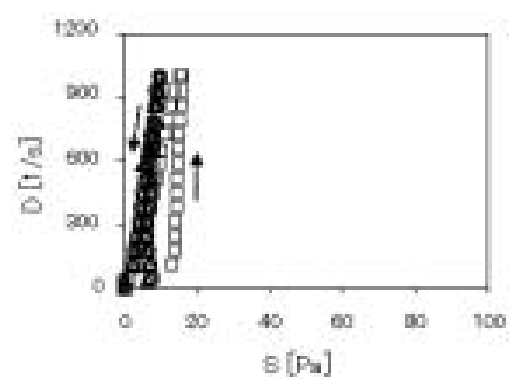

F

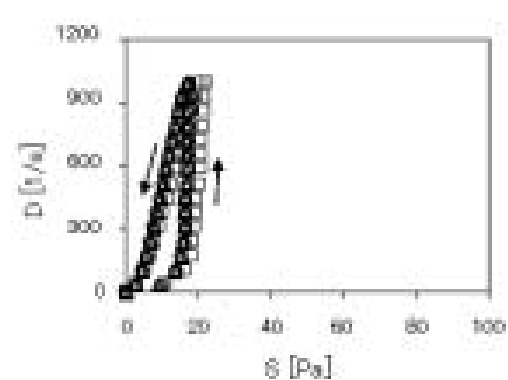

B

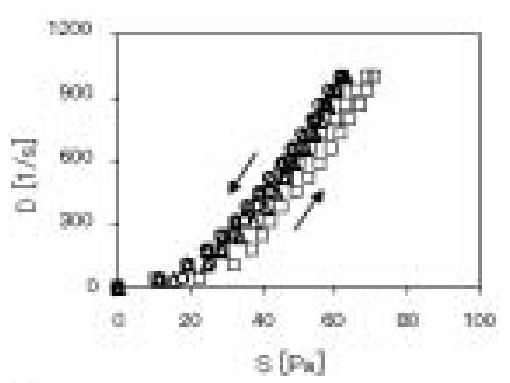

J

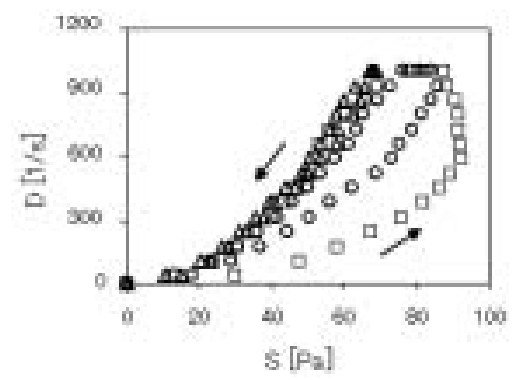

図 1 . 各種小児用嚥下補助ゼリーのレオロジー測定

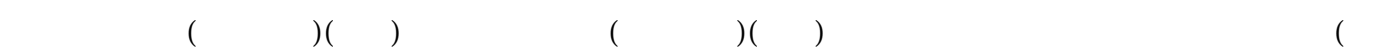
拌あり)( $\square$ 印)

$D$ : せん断速度 $(1 / \mathrm{s}), \mathrm{S}:$ 世ん断応力 $(\mathrm{Pa})$

A : ヨーグルト $, \mathrm{B}:$ ソフティア+アップルジュース , C : ソフティア+オレンジジュース ,D : ソフティ ア+アクエリアス, $\mathrm{E}:$ ソフティア+精製水 $, \mathrm{F}:$ ソフティア+ココア $\mathrm{G}$ : やさしく・おいしく水分補 給，H：お薬飲めたね(ピーチ味)，I：お薬飲めたね(いちこ味)，J：お薬飲めたね(チョコレート味) 
思われる . 弚の結果として , ドライシロップを添加した IIIに関しては，ヒステリシスループ面積の大幅な増加， すなわち基剤と薬剂による大きな物理的相互作用，つま り顕著なチキソトロピー特性か認められた .

以上の結果から，小児か薬を飲むときによく使用され るヨーグルトの流動曲線は, 降伏値を伴い, さらにチキ ソトロピー性を有する曲線(図 1 A)で, クラリスドライ シロップ添加時の流動曲線に近い小児用㵰下補助ゼリー は,やさしく・おいしく水分補給(図 $1 \mathbf{G}$ )であった .こ れは，薬剂をやさしく・おいしく水分補給と混ぜた後， 口の中で咀嚼し，飲み込むまでの流動状態がヨーグルト の場合と類似していることを示している．また，pHに 関しても，ヨーグルトは pH 4.28 に対してやさしく・お いしく水分補給は pH 3.81 と近い值であったことから， 弚の酸味による食感も類似していると思われる(表 1 ).

今回, 各種小児用嚥下補助ゼリーと薬剂を混合して, レオロジー測定を試みた。光の結果, 各種嚥下補助ゼ リーによって，光の流動曲線に大きな違いがあることが わかった . せん断速度とせん断応力による流動曲線を用 いることにより，降伏值やチキソトロピー特性を調べる ことができ，この結果を利用して产の製品についての食 感等の評価ができると思われる.例えば，チキソトロ ピ一性を有していない製品については，外力による粘度 変化をもたらさず，ゼリー自体をはじめからやわらかく することで飲み込みやすくしていることが考えられる． また，降伏值およびチキソトロピ一性のある製品に関し ては, 多少の外力に対して产の粘度は維持され, 薬剤を 混合した時点での懸濁安定化効果があり，薬斉の沈降を 抑えられる.一方，軽く振ったり，咀嚼して飲み込むな どのせん断応力がかかることにより，構造粘性が破壤さ れて液体の性質を強く示して飲みやすくなるなどの製剤 上の有利な特徵をもたらすことができると思われる．つ まり，薬斉を服用する段階において強い外力がかかり， 急激に粘度が低下することでなめらかに嚥下できること が考えられた .

以上の実験結果より，嚥下補助ゼリーの評価に対し て，レオロジー測定を行うことは有効な手段であること が示された . 今後 , こうしたレオロジーによる評価を取 り入れることは，嚥下補助ゼリ一の開発の省力化や多樣 性をもたらすとともに，小児にやさしい服用の一助にな ると期待される .

謝辞 本実験を行うにあたり，試料のご提供を頂きました 株式会社龍角散，ニュートリー株式会社，バランス株式会社 の皆樣に心から感謝致します．

\section{引用文献}

1) 虎石顕一, 中村規子, 由井薗陽一, 森真弓 , 山田正紀, 高橋司，黑川美智子，服薬拒否小児のコンプライアンス
向上のための市販菓子用即時型ゲル基剂の臨床応用, 病 院薬学, 24, 479-483 (1998).

2）鶴居勝也, 脇坂賢昇, 窪田真弓 , 竹内美千代, 田中基 裕, 服薬コンプライアンスの向上を目指した小児への散 薬服用方法の工夫, 日本病院薬剂師会杂隹誌, 41, 14151419 (2005).

3) 濱田潤，伊賀立二, 小児への薬の飲ませ方，薬局， 51， 1375-1379 (2000).

4) 鶴居勝也, 窪田真弓 , 脇坂賢昇, 小林德子 , 竹内美千 代 , 田中基裕 , 服薬コンプライアンスの向上を目指した 小児への散薬服用方法の工夫(第 2 報) - 小児用服薬指導 パンフレットの有用性について - , 日本病院薬剂師会雑 誌，42，1071-1074 (2006).

5) 木下博子, 小児への服薬指導と注意点 - 薬が飲めない 子，薬を飲まない子への支援一, 小巟科臨床，60，22692274 (2007).

6) 大越ひろ, テクスチャー調整食品-最近の傾向と使い方 のヒント - , 臨床栄養 , 51, 178-185 (2004).

7) 大越ひろ，4段階のテクスチャー調整食品 - 在宅療養者 にとって活用しやすい情報提供をめざして - , 難病と在 宅ケア，11，37-40 (2005).

8) 大越ひろ, 増粘剂(卜ロミ調整剂)の適切な使用方法, MEDICAL REHABILITATION , 57，132-139 (2005).

9) 高野喜久雄, 福居篤子, 高齢医療の現場における嚥下障 害 - 嚥下補助ゼリーの使用経験 - , リハビリテーション 医学, 38, 754-756 (2001).

10) 福居篤子, バリアフリー製剂を簡便に調製できる「服薬 を補助するゼリー状のオブラート」, 薬斉学 , 64,240 244 (2004).

11) 森田俊博, 服薬補助ゼリーの開発, 薬学杂倠誌, $123,665-$ 671 (2003).

12）福居篤子, 藤井隆太, 砂田久一, えん下補助ゼリ一の開 発, Development of Deglutition Aid Jelly, 薬斉学, 60 , 62-70 (2000).

13) 水上美樹, 田村文誉, 冨田かをり, 原朋美, 大河内昌 子, 向井美恵, 翠田彩洋子, 嚥下困難者用ゼリ一の物性 に関する適正評価 - 物性と官能評価による検討 - ，日捸 食嚥下リハ会誌, $7,47-52$ (2003).

14) O. N. Donkor, A. Henriksson, T. Vasiljevic, N. P. Shah, Rheological properties and sensory characteristics of set-type soy yogurt, J. Agric. Food Chem., 55 , 9868-9876 (2007).

15) T. Ozcan-Y ilsay, W-J. Lee, D. Horne, J. A. Lucey, Effect of trisodium citrate on rheological and physical properties and microstructure of yogurt, J. Dairy Sci., 90, 1644-1652 (2007).

16) M. Meriendez, B. Paredes, O. Iglesias, M. Rendueles, M. Díaz. Rheological behavior and organoleptic effects of ovalbumin addition in yogurt mousse production, J. Dairy Sci., 89 , 951-962 (2006).

17) M. Takeuchi, S. Kageyama, H. Suzuki, T. Wada, Y. Toyoda, T. Oguma, Y. Ezure, Y. Tsuriya, T. Kato, F. Ishii, Material Tech., 17 , 445-452 (1999).

18) M. Takeuchi, S. Kageyama, H. Suzuki, T. Wada, Y. Notsu, F. Ishii, Colloid Polym. Sci., 281, 1178-1183 (2003). 